\title{
DEVELOPING PROPOSED LAYOUT FOR INCREASING LINE EFFICIENCY ON BODYSHOP
}

\author{
Johan Oscar Ong and Cornellia \\ Faculty of Technology, Industrial Engineering Department, President University \\ Jl. Ki Hajar Dewantara \\ Kota Jababeka,Cikarang, Bekasi - Indonesia 17550 \\ Email: johanoscarong@gmail.com
}

\begin{abstract}
Recently, an imbalance workstation in the assembly line is one of the critical problem that many companies face. Many researches have done to solve this problem with the various designs of assembly line balancing. This research presents the comparison between straight line balancing and $u$-shaped line balancing. Both straight line balancing and u-shaped line balancing have the same goal; minimizing the workstations. The result of this research shows that $u$-shaped line balancing gives a better solution than the straight line balancing in term of number of workstation. Straight line balancing is using Rank Positional Weight (RPW) whereas u-shaped line balancing is using Critical Task Method (CTM). Significantly, u-shaped line balancing is more efficient than straight line balancing.
\end{abstract}

Keywords : assembly line balancing, straight line balancing, u-shaped line balancing, Rank Positional Weight, Critical Task Method

\section{INTRODUCTION}

Recently the automotive industry is growing rapidly. It leads the bodyshop's factory be a promising business because the automotive company could not stand itself without the bodyshop's activities. There are three kinds of bodyshop's activities; light repair, medium repair, and heavy repair. The standard time for light damage (1-3 panels) is 1 day or more and less than 3 days. For medium damage (4-6 panels) is 3 days or more and less than 5 days and for the heavy damage ( $\geq 7$ panels) is more than 5 days or around 2 weeks. Form the observation, it is found that the actual repair time of light damage is 4.44 working-days (more than 3 working-days) and the repair time of medium damage is 7.02 working-days (more than 5 working-days).

Based on the observation data above, the line efficiency of bodyshop is still low. The line of bodyshop is not balance, it makes many vehicles got stuck when entering the stalls. There are two types of assembly line balancing that matches for the condition of bodyshop; straight line balancing and u-shaped line balancing. Straight line balancing means a balance production line in which stations are arranged consecutively in a line by grouping tasks into stations while moving forward through a precedence diagram by using Rank Positional Weight. On the other hand, u-shaped line balancing is a balance production line is arranged by assigning tasks into stations while moving forward, backward, or simultaneously in both directions through the precedence diagram by using Critical Task Method.

\section{LITERATURE STUDY}

\section{A. Standard Time (Time Study)}

\section{Validity Test}

There are three kind of test to prove the observation's data is valid:

a. Normality Test

While confidence interval construction is about unknown population mean $\mu$ based upon the calculation of a point estimate and level of confidence, hypothesis testing allows an experimenter to assess the plausibility and credibility of a specific statement (Hayter, 2000). Actually, the state of $\mathrm{H}_{0}$ and $\mathrm{H}_{\mathrm{A}}$ could be explained below.

$\mathrm{H}_{0} \quad$ : The data is normally distributed 
$\mathrm{H}_{\mathrm{A}} \quad$ : The data is not normally distributed

If the $\mathrm{p}$-value $\leq \alpha$ (significance level), the null hypothesis is rejected. The significance level for this research is $5 \%$.

b. Uniformity Test

There are several steps to determine the uniformity of a set of data:

i. Calculate average observed time $(\overline{\mathrm{x}})$ for each operation.

$$
\bar{x}=\frac{\sum_{i=1}^{N} x i}{N}
$$

ii. Calculate the standard deviation (s) of each operation.

$$
s=\sqrt{\frac{\sum_{i-1}^{N}(x i-\bar{x})^{2}}{N-1}}
$$

iii. Determine the Upper Control Limit (UCL) and Lower Control Limit (LCL) (Wignjosoebroto, 2000).

$$
\begin{aligned}
& U C L=\bar{x}+3 s \\
& L C L=\bar{x}-3 s
\end{aligned}
$$

\section{iv. Suficiency Test}

The data is sufficient when n (number of data) greater than $\mathrm{N}^{\prime}$ (number of observation needed). The following formula is calculating how many observations must be done to reach 95\% confidence level (Sutalaksana, 2006).

$$
N^{\prime}=\left(\frac{40 \sqrt{N \cdot \sum x i^{2}-\left(\sum x i\right)^{2}}}{\sum x i}\right)^{2}
$$

\section{Rating Operator Performance (Westinghouse System)}

Niebel (2003) put the detail of westinghouse system as the rating method. This method considers four factors in evaluating the performance of operator; skill, effort, conditions, and consistency. The overall performance factor could be determined by algebraically combining the four values and adding their sum to unity.

\section{Adding Allowance}

Sutalaksana (2006) determines the factors as energy that be taken out, work posture, work motion, eye fatigue, temperature condition, atmosphere condition, and good environment condition. The evaluation is done by calculating the values of the seven factors, personal needs, and delays.

\section{B. Rank Positional Weight (Straight Line Balancing)}

There are some steps in Helgeson-Birnie Approach method to design assembly line:

1. Create the precedence matrix to show the relationship among those elements. The following figure is established to show the precedence matrix. The numeral 1 signifies a "must precedes" relationship.

2. Calculate Positional Weight (PW) for every work element (WE).

3. Sort all work elements from the largest PW until the smallest PW. Listing all the positional weight in decreasing order of magnitude.

4. Based on the rank of PW in step 2, develop the task loading into work station. Because of that, there will be some limitations:

- The relation in Precedence Diagram (+Status zone/ zone constraints) 
- Work station time (ST) could not be more than actual cycle time (CTi)

5. Calculate the work station's efficiency and efficiency of assembly line (LE).

\section{Critical Task Method (U-Shaped Line Balancing)}

Yeh and Kao (2009) in Fathi et all (2011) proposed a new approach based on critical path methods (CPM) in order to solve bidirectional assembly lines, and the time complexity of this method is only $\mathrm{O}(\mathrm{mn} 2)$, meaning that this method can be solved within a polynomial-time. Because of the advantage of less time complexity, in this study the effective heuristic method is presented which is based on combining the proposed approach by Yeh and Kao (2009) and the well-known rank positional weight technique (RPW) introduced by Helgeson and Birnie (1961) to solve U-shape assembly line problems in the area of type-1. There are several steps to do the CTM:

1. Calculating minimum feasible number of workstation $\mathrm{S}$ and the minimum feasible cycle time MCT and the adjusted value of $\mathrm{CT}^{*}=(\mathrm{MCT}+\mathrm{CT}) / 2$.

2. Creating a new workstation, calculating the weight for each task in two stages, one time from the forward direction and another time from the backwards direction and then identifying activities permitted for assigning and creating a candidate list.

3. Assigning activities with high weight on the candidate list; if there are two or more activities with the same weight one of them can be selected to be assigned at random. This order in each stage is continued by finding the new weight for each task using the critical path, because when solving U-shape line the tasks' weight should be updated in the forward direction when the assigned task is from the end of network; otherwise, the tasks' weight in the backward direction should be calculated again, until all the activities are assigned to the workstations.

4. Computing the remaining time for the current station and updating the candidate list based on the new calculated weights and constraints; if the station has enough time for any feasible unassigned task go to step 3, otherwise go to step 5.

5. The assigning process will be repeated until no tasks are left. If there are unassigned tasks, go to step 2.

\section{Activity Relationship Chart}

Activity Relationship Chart (ARC) can be defined as the maping of activity relation that describe the closeness degree of every facility. Mulyati and Rachmi (2011) set the main goal of ARC is to know the relationship closeness of each group's activity in terms of factory organization. There are six symbols of ARC's closeness degree.

Table 1. Table closeness degree

\begin{tabular}{|l|l|}
\hline Code & Closeness Degree \\
\hline A & Absolutely necessary \\
\hline E & Especially important \\
\hline I & Important \\
\hline O & Ordinary closeness OK \\
\hline X & Undesirable \\
\hline U & Unimportant \\
\hline
\end{tabular}

The dimensionless block diagram is the first attempt and the result of the ARC. This layout will be the basis for the master layout and plot plan. The following table is the position requirements of placing the relationship codes. 
Table 2. Position in dimensionless block diagram

\begin{tabular}{|c|l|}
\hline Code & \multicolumn{1}{|c|}{ Position } \\
\hline A & in the top left-hand corner \\
\hline E & top right corner \\
\hline I & bottom left corner \\
\hline O & bottom right corner \\
\hline U & relationship omitted \\
\hline X & in the center under the department number \\
\hline
\end{tabular}

\section{E. Simulation Modelling}

A model is a simplified representation of reality, the exact way in whuch an operation is performed is not so important as the way in which the operation impacts the rest of the system (Harrell et al, 2012). There are four basic of model building in Simulation Modelling (Promodel 7): location, entities, arrival, and processing.

\section{Bonferroni Approach}

In Harrell et al. (2012), the statistical methods for making the comparison of system are called hypotheses tests. One of the methods that could be used is Bonferroni Approach. When there are three to about five alternative system designs to compare with respect to some performance measure, the Bonferroni approach is the method to solve it. Given $\mathrm{K}$ alternative system designs to compare, the null hypothesis $\mathrm{H} 0$ and alternative hypothesis $\mathrm{H} 1$ become :

$$
\begin{array}{cl}
\mathrm{H}_{0}: \mu_{1}=\mu_{2}=\mu_{3}=\ldots=\mu_{\mathrm{k}}=\mu & \text { for } \mathrm{K} \text { alternative systems } \\
\mathrm{H}_{1}: \mu_{\mathrm{i}} \neq \mu_{\mathrm{i}}, & \text { for at least one pair } \mathrm{i} \neq \mathrm{i}
\end{array}
$$

where $\mathrm{i}$ and i' are between 1 and $\mathrm{K}$ and $\mathrm{i}<\mathrm{i}$ '.

The number of pairwise comparisons for $\mathrm{K}$ candidate designs is computed by $\mathrm{K}(\mathrm{K}-$ 1) / 2.

\section{Model Verification and Model Validation}

There is a way to do the model verification; using trace and debugging facilities. Comparing with the actual system is one of the techniques that could be used to validate the model. Using the paired-t test for comparing the model with the actual system. In paired-t test, it is necessary for testing the hypotheses;

$$
\begin{aligned}
& \mathrm{H}_{0}: \mu_{1}-\mu_{2}=0 \\
& \mathrm{H}_{1}: \mu_{1}-\mu_{2} \neq 0
\end{aligned}
$$

Thus, the paired-t confidence interval for an $\alpha$ level of significance is

$$
\mathrm{P}\left(\overline{\mathrm{x}}_{(1-2)}-\mathrm{hw} \leq \mu_{(1-2)} \leq \overline{\mathrm{x}}_{(1-2)}+\mathrm{hw}\right)=1-\alpha
$$

\section{F. Line Efficiency, Smoothness Index, and Balance Delay}

There are three parameters in designing the assembly line balancing.

- The efficiency of assembly line (ratio between total workstation time and multification of cycle time and number of workstations).

$$
L E=\frac{\sum_{i=0}^{K} S T i}{(K)(C T)} \times 100 \%
$$

\footnotetext{
$L E=$ efficiency of assembly line

$S T i=$ workstation time $\mathrm{i}$

$K$ = number of workstations

$C T=$ cycle time
} 
- The smoothness index (index that shows the relative smoothness of the assembly line).

$$
S I=\sqrt{\sum_{i=1}^{K}(S T \max -S T i)^{2}}
$$

$S I=$ smoothness index

STmax $=$ maximum workstation time

$S T i=$ workstation time $\mathrm{i}$

- The balance delay (the rate of delay).

$$
B D=(K) \frac{(\text { STmax })-\sum_{i=1}^{K} t i x}{(K)(\text { STmax })} 100 \%
$$

$$
\begin{aligned}
& B D=\text { balance delay } \\
& K=\text { number of workstation } \\
& S T \text { max }=\text { maximum workstation time } \\
& t i=\text { work element time }
\end{aligned}
$$

\section{RESEARCH METHODOLOGY}

\section{A. Initial Observation}

In this stage, it was observed the current condition in the line by using direct observation and interview. The objective of this step is to understand the actual problem occurred in the line.

\section{B. Data Collection and Calculation}

The steps for conducting the data collection and calculation are follows:

1. Determining the work elements.

2. Determining the standard time of each work element/operation using time motion study.

3. Determining the proposed line using Rank Positional Weight method (Straight Line) and using Critical Task Method (U-Shaped)

4. Designing the layout for straight line flow and u-shaped flow from the result of line balancing method from step 3 .

5. Conducting the simulation for the proposed line with straight line flow and ushaped flow. Simulation is conducted using Promodel software. The verification is done by using the software trace in the Promodel and the validation is done using bonferroni approach.

\section{Analysis}

Compare the current condition and proposed line balancing in line efficiency, smoothness index, and balance delay.

\section{DATA COLLECTION AND ANALYSIS}

\section{A. Current Condition}

Current work arrangement and yamazumi chart below identifies the two facts about actual time; some workstations violate the takt time (workstation 4, 5, and 7), the process is rough from one workstation to another. The standard time for all work elements are attached as Appendix 1. 
Table 3. Actual cycle time of work arrangement

\begin{tabular}{|l|l|c|c|}
\hline No & \multicolumn{1}{|c|}{ Operation } & $\begin{array}{c}\text { Workstation } \\
\text { Time (min) }\end{array}$ & $\begin{array}{c}\text { Number of } \\
\text { operator }\end{array}$ \\
\hline 1 & Q1 + Q2 +Q3 & 4,69 & 1 \\
\hline 2 & Q4 + Q5 + Q6 + Q7 + Q8 & 7,53 & 1 \\
\hline 3 & Q9 + Q10 + Q11 + Q12 & 22,41 & 1 \\
\hline 4 & Q13 + Q14 + Q15 + Q16 + Q17 + Q18 & 64,76 & 1 \\
\hline 5 & Q19 + Q20 + Q21 + Q22 + Q23 + Q24 + Q25 + Q26 + Q27 + Q28 & 60,28 & 1 \\
\hline 6 & Q29 + Q30 + Q31 + Q32 + Q33 + Q34 & 20,84 & 1 \\
\hline 7 & $\begin{array}{l}\text { Q35 + Q36 + Q37 + Q38 + Q39 + Q40 + Q41 + Q42 + Q43 + Q44 } \\
\text { + Q45 }\end{array}$ & 55,12 & 1 \\
\hline 8 & Q46 + Q47 & 3,18 & 1 \\
\hline \multicolumn{2}{|c|}{ Total } & 238,82 & 8 \\
\hline
\end{tabular}

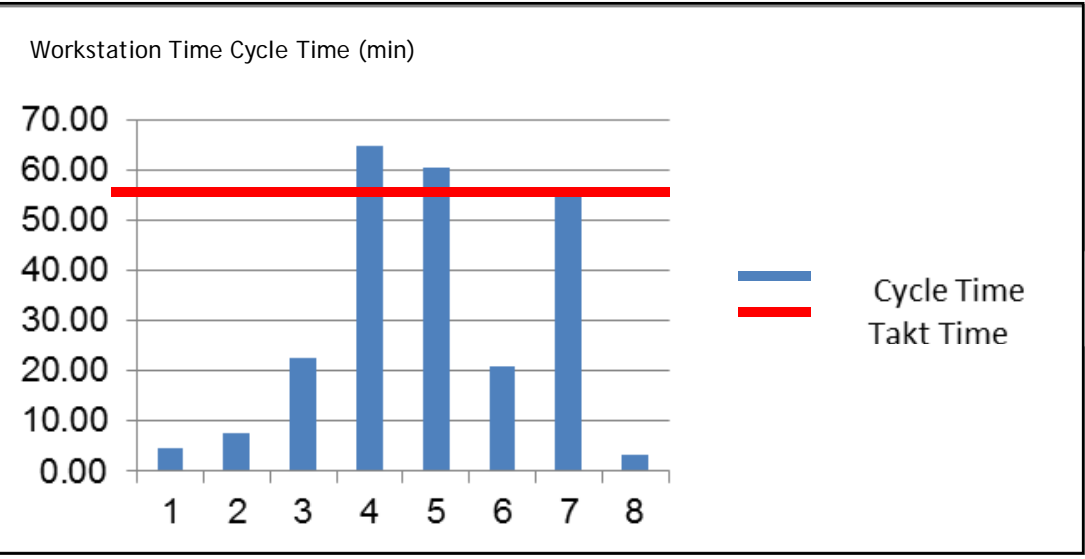

Figure 1. Actual yamazumi chart of bodyshop

The line efficiency of current condition is calculated using formula number 5 and the result is:

$$
L E=\frac{238,82}{8 \times 64,76} \times 100 \%=46,1 \%
$$

The smoothness index of each process is shown below:

Table 4. Smoothness Index of Current Line

\begin{tabular}{|c|r|r|}
\hline Operator & \multicolumn{1}{|c|}{ STi } & \multicolumn{1}{|c|}{${\text { (STmax-STi })^{2}}^{2}$} \\
\hline 1 & 4,69 & 3608,79 \\
\hline 2 & 7,53 & 3274,80 \\
\hline 3 & 22,41 & 1793,21 \\
\hline 4 & 64,76 & 0,00 \\
\hline 5 & 60,28 & 20,06 \\
\hline 6 & 20,84 & 1928,91 \\
\hline 7 & 55,12 & 92,89 \\
\hline 8 & 3,18 & 3792,13 \\
\hline \multicolumn{2}{|c|}{ Total } & 14510,79 \\
\hline \multicolumn{2}{|c|}{ Smoothness Index } & 120,46 \\
\hline
\end{tabular}

Due to bottleneck and idle time which occur in the bodyshop line, a delay arises. The value of delay is calculated below. 


$$
B D=\frac{(8)(64,76)-238,82}{(8)(64,76)} \times 100 \%=53,9 \%
$$

\section{B. Proposed Straight Line using Rank Positional Weight}

To propose the straight line flow of the line balancing is employed the Rank Positional Weight (RPW) based on the precedence diagram (see Appendix 2). The details calculation of each operation's weight is shown as Appendix 3. The example of calculation the weight of operation Q1 is shown below. Since Q1 precedes all operations except Q22, Q26, Q32, and Q45, the operational weight of Q1 is:

$$
\begin{aligned}
& \sum 1, Q 2, Q 3, Q 4, Q 5, Q 6, Q 7, Q 8, Q 9, Q 10, Q 11, Q 12, Q 13, Q 14, Q 15, Q 16, Q 17 \\
& Q 18, Q 19, Q 20, Q 21, Q 23, Q 24, Q 25, Q 27, Q 28, Q 29, Q 30, Q 31, Q 33, Q 34 \\
& Q 35, Q 36, Q 37, Q 38, Q 39, Q 40, Q 41, Q 42, Q 43, Q 44, Q 46, Q 47 \\
& =0,92+1,34+2,44+1,50+1,84+2,76+1,09+0,36+2,01+7,74+3,23+9,44+5,19+0,84 \\
& +44,38+1,52+11,72+1,12+4,74+2,58+0,63+0,50+1,40+2,63+10,09+34,85+1,92+ \\
& 3,87+3,64+4,93+2,65+3,01+6,94+2,41+7,95+3,68+2,04+13,31+1,93+5,60+2,79+ \\
& 1,77+1,41 \\
& =226.66
\end{aligned}
$$

RPW.

The table below is the work arrangement of straight line balancing based on

Table 6 Proposed work arrangement of straight line (RPW)

\begin{tabular}{|c|l|r|c|}
\hline Workstation & \multicolumn{1}{|c|}{ Operation } & \multicolumn{1}{|c|}{$\begin{array}{c}\text { Workstation } \\
\text { Time (min) }\end{array}$} & $\begin{array}{c}\text { Number of } \\
\text { operator }\end{array}$ \\
\hline 1 & $\begin{array}{l}\text { Q1 + Q2 + Q3 + Q4 + Q5 + Q6 + Q7 + Q8 + Q9 + Q10 } \\
+ \text { Q11 + Q12 + Q13 }\end{array}$ & 39,52 & 1 \\
\hline 2 & Q14 + Q15 + Q16 & 46,74 & 1 \\
\hline 3 & $\begin{array}{l}\text { Q17 + Q18 + Q19 + Q20 + Q21 + Q22 + Q23 + Q24 + } \\
\text { Q25 }\end{array}$ & 26,2 & 1 \\
\hline 4 & Q26 + Q27 + Q28 & 46,92 & 1 \\
\hline 5 & $\begin{array}{l}\text { Q29 + Q30 + Q31 + Q32 + Q33 + Q34 + Q35 + Q36 + } \\
\text { Q37 + Q38 + Q39 }\end{array}$ & 44,84 & 1 \\
\hline 6 & Q40 + Q41 + Q42 + Q43 + Q44 + Q45 + Q46 + Q47 & 34,32 & 1 \\
\hline \multicolumn{2}{|c|}{ TOTAL } & 238,54 & 6 \\
\hline
\end{tabular}

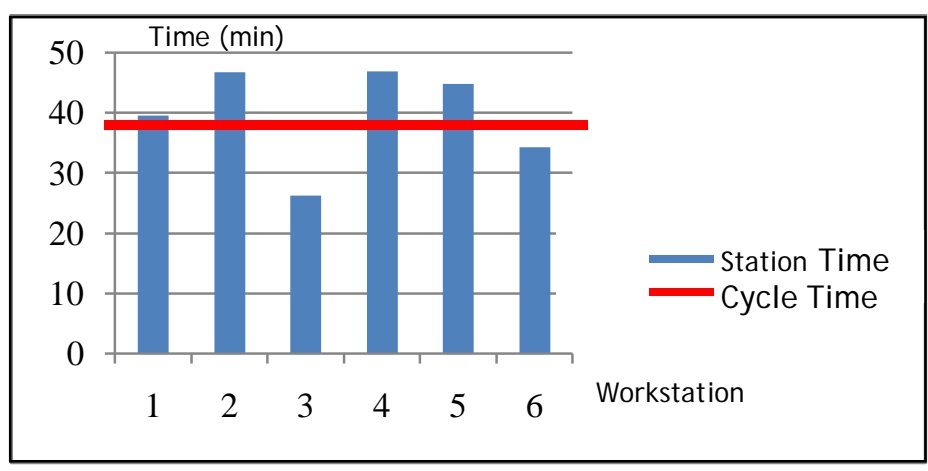

Figure 4 Yamazumi Chart of proposed straight line

The calculation of the line efficiency and smoothness index for the proposed straight line using RPW are shown as table 7 and table 8 below. 
Table 7 Calculation of straight line efficiency

\begin{tabular}{|r|r|r|r|r|}
\hline Workstation & Station Time (min) & Operator & Idle Time (min) & Line Efficiency \\
\hline 1 & 39,52 & 1 & 8,48 & $82,3 \%$ \\
\hline 2 & 46,74 & 1 & 1,26 & $97,4 \%$ \\
\hline 3 & 26,20 & 1 & 21,80 & $54,6 \%$ \\
\hline 4 & 46,92 & 1 & 1,08 & $97,8 \%$ \\
\hline 5 & 44,84 & 1 & 3,16 & $93,4 \%$ \\
\hline 6 & 34,32 & 1 & 13,68 & $71,5 \%$ \\
\hline \multicolumn{5}{|c|}{ Average } \\
\hline
\end{tabular}

Table 8 Calculation of smoothness index for straight line

\begin{tabular}{|r|r|r|}
\hline Operator & \multicolumn{1}{|c|}{ STi } & (STmax-STi) $^{2}$ \\
\hline 1 & 39,52 & 54,76 \\
\hline 2 & 46,74 & 0,03 \\
\hline 3 & 26,2 & 429,32 \\
\hline 4 & 46,92 & 0,00 \\
\hline 5 & 44,84 & 4,33 \\
\hline 6 & 34,32 & 158,76 \\
\hline \multicolumn{2}{|c|}{ Total } & 647,20 \\
\hline Smoothness Index & 25,44 \\
\hline
\end{tabular}

Below is the calculation of Balance Delay:

$$
\begin{gathered}
B D=\frac{(6)(46,92)-238,82}{(6)(46,92)} \times 100 \% \\
B D=15,2 \%
\end{gathered}
$$

It shows that the line efficiency of the proposed line is higher than the line efficiency of current line and the balance delay of the proposed line is lower than the balance delay of the current line. The balance delay has been decreased to $15,2 \%$. It means the bottleneck or idle time will be reduced.

It could be beneficial to design the layout of straight line balancing. The Activity relationship chart is employed for designing the layout. The ARC is shown as table 9 below.

Table 9. ARC of straight line balancing

\begin{tabular}{|c|l|l|c|}
\hline NO & Facility & Relationship \\
\hline 1 & Workstation 1 & Workstation 2 \\
\hline 3 & Workstation 3 & Workstation 4 \\
\hline 5 & Workstation 5 & Workstation 6
\end{tabular}


Below is the dimensionless block diagram (layout) for straight line balancing.

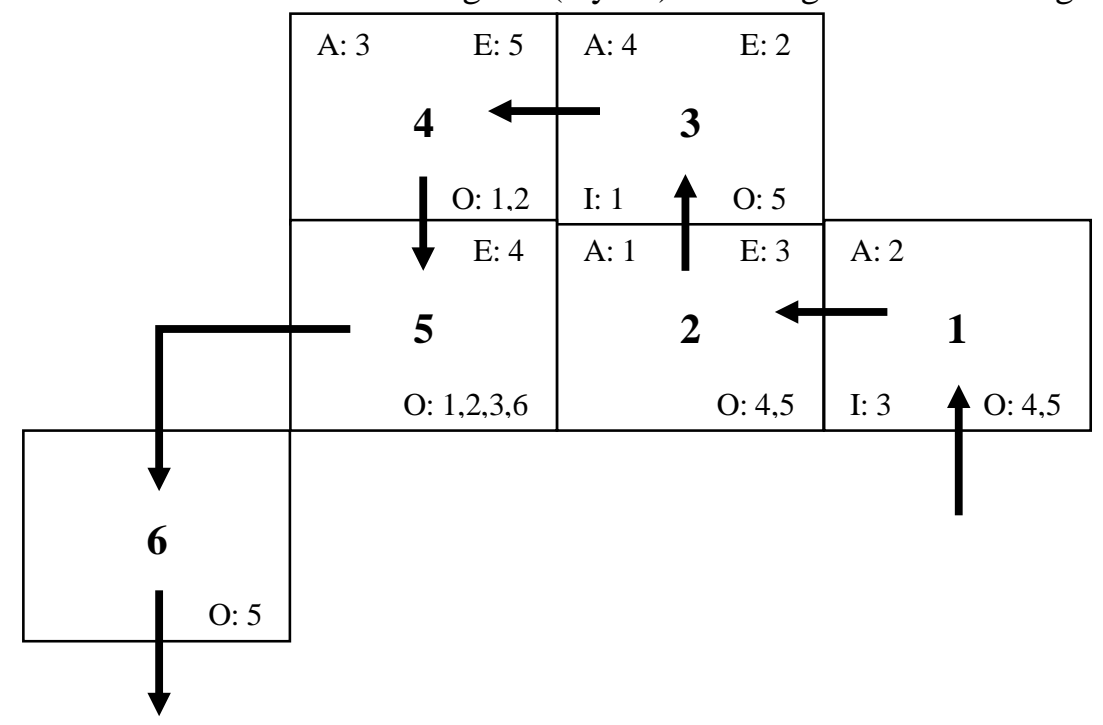

Figure 5. Dimensionless block diagram of straight line balancing

\section{Proposed U-Shaped Line using Critical Tasks Method}

To propose the U-shaped line flow of the line balancing is employed the Critical Tasks Method (CTM). The details calculation of CTM is shown as Appendix 4. The example of calculating backward and forward weight for $\mathrm{Q}_{1}$ is.

Backward:

$\Sigma^{Q 1}, Q 3, Q 5, Q 6, Q 8, Q 9, Q 10, Q 13, Q 14, Q 16, Q 17, Q 19, Q 21, Q 23, Q 24, Q 25, Q 27$

$\sum \quad Q 29, Q 30, Q 31, Q 33, Q 34, Q 35, Q 36, Q 37, Q 38, Q 41, Q 42, Q 43, Q 44, Q 46, Q 47$

$=0,92+2,44+1,84+2,76+0,36+2,01+7,74+5,19+0,84+1,52+11,72+4,74+0,63+0,50+1,40+$

$2,63+10,09+1,92+3,87+3,64+4,93+2,65+3,01+6,94+2,41+7,95+13,31+1,93+5,60+2,79+$

$1,77+1,41=121,43$

Forward: Q1 = 0,92

The work arrangement of each station can be seen as table 10 below.

Table 10. Proposed work arrangement of u-shaped line (CTM)

\begin{tabular}{|c|l|r|c|}
\hline Workstation & \multicolumn{1}{|c|}{ Operation } & \multicolumn{1}{|c|}{$\begin{array}{c}\text { Workstation } \\
\text { Time (min) }\end{array}$} & $\begin{array}{c}\text { Number of } \\
\text { operator }\end{array}$ \\
\hline 1 & $\begin{array}{l}\text { Q1 + Q2 + Q3 + Q4 + Q5 + Q6+ Q7 + Q8 + Q31 + } \\
\text { Q32 + Q33 + Q34 + Q35 + Q36 + Q37 + Q38 }\end{array}$ & 47,58 & 1 \\
\hline 2 & $\begin{array}{l}\text { Q9 + Q10 + Q39 + Q40 + Q41 + Q42 + Q43 + Q44 } \\
\text { + Q45 + Q46 + Q47 }\end{array}$ & 47,75 & 1 \\
\hline 3 & $\begin{array}{l}\text { Q11 + Q12 + Q13 + Q17 + Q19 + Q20 + Q21 + } \\
\text { Q23 + Q24 + Q25 +Q29 + Q30 }\end{array}$ & 47,85 & 1 \\
\hline 4 & Q14 + Q15 + Q16 + Q18 & 47,86 & 1 \\
\hline 5 & Q26 + Q27 + Q28 + Q22 & 47,79 & 1 \\
\hline \multicolumn{2}{|c|}{ Average } & 238,82 & 5 \\
\hline
\end{tabular}




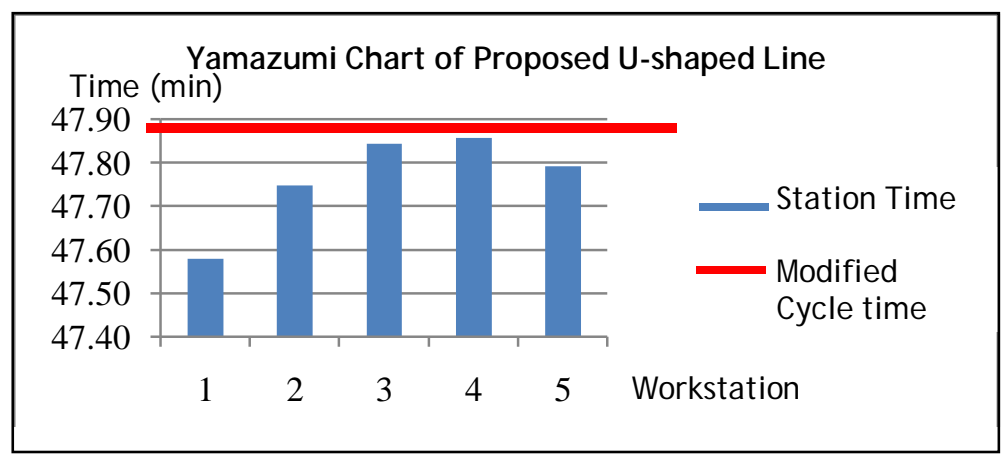

Figure 6. Yamazumi chart of proposed u-shaped line

The calculation of the line efficiency and smoothness index for the proposed Ushaped line using CTM are shown as table 11 and table 12 below.

Table 11. Calculation of u-shaped Efficiency

\begin{tabular}{|c|c|c|c|c|}
\hline $\begin{array}{l}\text { Work } \\
\text { Station }\end{array}$ & $\begin{array}{c}\text { Station } \\
\text { Time (min) }\end{array}$ & $\begin{array}{c}\text { Number } \\
\text { of } \\
\text { Operator }\end{array}$ & $\begin{array}{l}\text { Idle Time } \\
\text { (min) }\end{array}$ & $\begin{array}{c}\text { Line } \\
\text { Efficiency }\end{array}$ \\
\hline 1 & 47,58 & 1 & 0,30 & $99,37 \%$ \\
\hline 2 & 47,75 & 1 & 0,13 & $99,73 \%$ \\
\hline 3 & 47,85 & 1 & 0,03 & $99,93 \%$ \\
\hline 4 & 47,86 & 1 & 0,02 & $99,95 \%$ \\
\hline 5 & 47,79 & 1 & 0,09 & $99,82 \%$ \\
\hline \multicolumn{3}{|c|}{ Average } & 0,12 & $99,76 \%$ \\
\hline
\end{tabular}

Table 12. Calculation of Smoothness Index for U-Shaped Line

\begin{tabular}{|r|c|r|}
\hline Work Station & STi & (STmax-STi $^{2}$ \\
\hline 1 & 47,58 & 0,077 \\
\hline 2 & 47,75 & 0,012 \\
\hline 3 & 47,85 & 0,000 \\
\hline 4 & 47,86 & 0,000 \\
\hline 5 & 47,79 & 0,004 \\
\hline \multicolumn{2}{|c|}{ Total } & 0,093 \\
\hline \multicolumn{2}{|c|}{ Smoothness Index } & 0,305 \\
\hline
\end{tabular}

Below is the calculation of Balance Delay of proposed u-shaped line.

$$
\begin{gathered}
B D=\frac{(5)(47,86)-238,82}{(6)(47,86)} \times 100 \% \\
B D=0,2 \%
\end{gathered}
$$

It shows that the line efficiency of the proposed line using CTM is the highest. The balance delay is very small.. Thus, there is no bottleneck on bodyshop.

The table of ARC for u-shaped line balancing is shown as table 13 below. 
Table 13 ARC of u-shaped line balancing

\begin{tabular}{|l|l|l|l|}
\hline NO & Facility & Relationship \\
\hline 1 & Workstation 1 & Workstation 2 \\
\hline 2 & Workstation 3 & Workstation 4 \\
\hline 4 & Workstation 5 &
\end{tabular}

Dimensionless block diagram is the layout of proposed u-shaped line balancing.

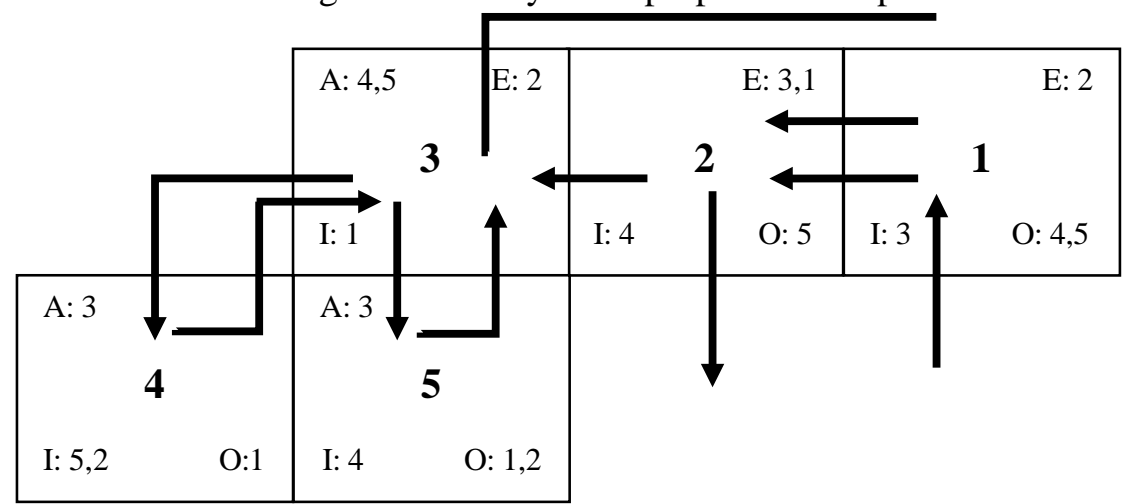

Figure 7. Dimensionless block diagram of straight line balancing

\section{Simulation}

In order to conduct the further study of the current and proposed line, the simulation is performed using Promodel. All simulation models are verify and valid. Model validation is tested by using paired-t (benferroni approach).

For the current condition, model validation is tested by using paired-t (comparing with actual system of bodyshop). It is the calculation of paired-t confidence intervals for the current line.

Comparing $\mu_{(\mathrm{A}-\mathrm{C})}: \alpha=0.05 \rightarrow$ The approximate $95 \%$ confidence interval:

$$
\begin{array}{ll}
h w=\frac{\left(t_{22,0.05}\right) s_{(A-C)}}{\sqrt{n}} & \bar{x}_{(A-C)}-h w \leq \mu_{(A-C)} \leq \bar{x}_{(A-C)}+h w \\
h w=\frac{(1.717) 0.95}{\sqrt{23}} & 0.43-0.56 \leq \mu_{(\mathrm{A}-\mathrm{C})} \leq 0.43+0.56 \\
h w=0.56 \text { unit per hour } & -0.12 \leq \mu_{(\mathrm{A}-\mathrm{C})} \leq 0.99
\end{array}
$$

Given that the confidence interval about $\mu_{(\mathrm{A}-\mathrm{C})}$ includes zero, it is concluded that there is no significant difference in the mean throughput produced by Actual System $\left(\mu_{\mathrm{A}}\right)$ and Current Line in ProModel $\left(\mu_{\mathrm{C}}\right)$. Thus, the model of current line in ProModel is right (validation and verification). There are 7.48 finished repair vehicles that are found in the finished stall. This is the output of current line in the simulation.

For the straight line using RPW, there are three model system designs; system 1 15 operators (station $1=2 \mathrm{opt}$, station $2=3 \mathrm{opt}$, station $3=2 \mathrm{opt}$, station $4=3 \mathrm{opt}$, station $5=3 o p t$, station $6=2 o p t$ ), system $2-16$ operators (station $1=2 o p t$, station $2=3 o p t$, station $3=2 o p t$, station $4=3$ opt, station $5=3 o p t$, station $6=3$ opt), and system $3-15$ operators (station $1=3$ opt, station $2=3$ opt, station $3=2$ opt, station $4=3$ opt, station $5=$ 3opt, station $6=2 \mathrm{opt}$ ). Using the benferroni approach to compare these systems. Below is the calculation of paired-t confidence intervals. 
- Comparing $\mu_{(1-2):}: \alpha_{1=} 0.02 \rightarrow$ The approximate $98 \%$ confidence interval:

$$
\begin{aligned}
& h w=\frac{\left(t_{22,0.01}\right) s_{(1-2)}}{\sqrt{n}} \\
& h w=\frac{(2.508) 0.73}{\sqrt{23}} \\
& h w=0.38 \text { unit per hour }
\end{aligned}
$$

$$
\begin{aligned}
\bar{x}_{(1-2)}- & h w \leq \mu_{(1-2)} \leq \bar{x}_{(1-2)}+h w \\
& -0.48-0.38 \leq \mu_{(1-2)} \leq-0.48+0.38 \\
& -0.86 \leq \mu_{(1-2)} \leq-0.10
\end{aligned}
$$

- Comparing $\mu_{(1-3)}: \alpha_{2}=0.02$

The approximate $98 \%$ confidence interval:

$$
\begin{aligned}
h w & =\frac{\left(t_{22,0.01}\right) s_{(1-3)}}{\sqrt{n}} \\
h w & =\frac{(2.508) 1.12}{\sqrt{23}} \\
h w & =0.59 \text { unit per hour }
\end{aligned}
$$

- Comparing $\mu_{(2-3)}: \alpha_{1}=0.02$

$$
\begin{aligned}
h w & =\frac{\left(t_{22,0.01}\right) s_{(2-3)}}{\sqrt{n}} \\
h w & =\frac{(2.508) 0.84}{\sqrt{23}} \\
h w & =0.44 \text { unit per hour }
\end{aligned}
$$

$$
\begin{aligned}
\bar{x}_{(1-3)}-h w & \leq \mu_{(1-3)} \leq \bar{x}_{(1-3)}+h w \\
- & 0.91-0.59 \leq \mu_{(1-3)} \leq-0.91+0.59 \\
-1.50 & \leq \mu_{(1-3)} \leq-0.32
\end{aligned}
$$

The approximate $98 \%$ confidence interval:

$$
\begin{aligned}
\bar{x}_{(2-3)}-h w \leq \mu_{(2-3)} \leq \bar{x}_{(2-3)}+h w \\
-0.43-0.44 \leq \mu_{(2-3)} \leq-0.43+0.44 \\
-0.88 \leq \mu_{(2-3)} \leq 0.01
\end{aligned}
$$

Based on these results, the System 1 is the least favorable with respect to the mean throughtput while System 2 and System 3 are the most favorable with respect to mean throughput. Thus, the recommendation is implementing the System 3 in place of the System 2 because System 3 was the boss's idea.

Model validation is tested by using paired-t (comparing with the calculation of maximum production capacity). Below is the calculation of maximum production capacity.

$\mathrm{P}=\mathrm{T} / \mathrm{C} \longrightarrow \mathrm{P}=480 / 46.92=10.23 \approx 10$

Suppose that overall significance level is $5 \%(\alpha=0.05)$. Below is the calculation of paired-t confidence intervals.

- Comparing $\mu_{(\mathrm{C}-\mathrm{S})}: \alpha=0.05 \rightarrow$ The approximate $95 \%$ confidence interval:

$$
\begin{aligned}
h w & =\frac{\left(t_{22,0.05}\right) s(C-S)}{\sqrt{n}} & \bar{x}_{(C-S)}-h w \leq \mu_{(C-S)} \leq \bar{x}_{(C-S)}+h w \\
h w & =\frac{(1.717) 0.80}{\sqrt{23}} & -0.22-0.28 \leq \mu_{(C-S)} \leq-0.22+0.28 \\
h w & =0.28 \text { unit per hour } & -0.50 \leq \mu_{(C-S)} \leq 0.06
\end{aligned}
$$

Given that the confidence interval about $\mu_{(\mathrm{C}-\mathrm{s})}$ includes zero, it is concluded that there is no significant difference in the mean throughput produced by calculation of maximum production capacity $\left(\mu_{\mathrm{C}}\right)$ and proposed straight line in ProModel $\left(\mu_{\mathrm{S}}\right)$. Thus, the model of proposed straight line in ProModel is verify and valid. The output of proposed straight line is 11,22 finished repair vehicles in the simulation.

For the U-Shaped line, there are also three model system designs; system 1 - 15 operators (station $1=3$ opt, station $2=3$ opt, station $3=3$ opt, station $4=3$ opt, station $5=$ 3opt), system 2 - 14 operators (station 1= 2opt, station 2=3opt, station 3=3opt, station $4=3 o p t$, station $5=3 o p t$ ), and system 3 - 16 operators (station $1=3 o p t$, station $2=3$ opt, station $3=3$ opt, station $4=4 \mathrm{opt}$, station $5=3 \mathrm{opt}$ ).. Below is the calculation of paired-t confidence intervals.

- Comparing $\mu_{(1-2)}: \alpha_{1=} 0.02 \longrightarrow$ The approximate $98 \%$ confidence interval:

$$
\begin{aligned}
h w & =\frac{\left(t_{22,0.01}\right) s_{(1-2)}}{\sqrt{n}} \\
h w & =\frac{(2.508) 1,10}{\sqrt{23}} \\
h w & =0.57 \text { unit per hour }
\end{aligned}
$$

$$
\begin{gathered}
\bar{x}_{(1-2)}-h w \leq \mu_{(1-2)} \leq \bar{x}_{(1-2)}+h w \\
1.13-0.57 \leq \mu_{(1-2)} \leq 1.13+0.57 \\
0.56 \leq \mu_{(1-2)} \leq 1.70
\end{gathered}
$$

- Comparing $\mu_{(1-3)}: \alpha_{2}=0.02 \longrightarrow$ The approximate $98 \%$ confidence interval: 


$$
\begin{aligned}
h w & =\frac{\left(t_{22,0.01}\right) s_{(1-3)}}{\sqrt{n}} \\
h w & =\frac{(2.508) 1,16}{\sqrt{23}} \\
h w & =0.61 \text { unit per hour }
\end{aligned}
$$

- Comparing $\mu_{(2-3)}: \alpha_{1=} 0.02$

$$
\begin{aligned}
h w & =\frac{\left(t_{22,0.01}\right) s_{(2-3)}}{\sqrt{n}} \\
h w & =\frac{(2.508) 0,89}{\sqrt{23}} \\
h w & =0.47 \text { unit per hour }
\end{aligned}
$$

$$
\begin{gathered}
\bar{x}_{(1-3)}-h w \leq \mu_{(1-3)} \leq \bar{x}_{(1-3)}+h w \\
-0.48-0.61 \leq \mu_{(1-3)} \leq-0.48+0.61 \\
-1.09 \leq \mu_{(1-3)} \leq 0.13
\end{gathered}
$$

The approximate $98 \%$ confidence interval:

$$
\begin{aligned}
\bar{x}_{(2-3)}-h w & \leq \mu_{(2-3)} \leq \bar{x}_{(2-3)}+h w \\
- & -61-0.47 \leq \mu_{(2-3)} \leq-1.61+0.47 \\
- & -2.08 \leq \mu_{(2-3)} \leq-1.14
\end{aligned}
$$

Based on these results, the System 1 is the least favorable with respect to the mean throughtput while System 2 and System 3 are the most favorable with respect to mean throughput. Model validation is tested by using paired-t (comparing with the calculation of maximum production capacity). Below is the calculation of maximum production capacity.

$\mathrm{P}=\mathrm{T} / \mathrm{C} \longrightarrow \mathrm{P}=480 / 46.92=10.23 \approx 10$

Suppose that overall significance level is $5 \%(\alpha=0.05)$. Below is the calculation of paired-t confidence intervals.

- Comparing $\mu_{(\mathrm{C}-\mathrm{U})}: \alpha=0.05 \rightarrow$ The approximate $95 \%$ confidence interval:

$$
\begin{aligned}
h w & =\frac{\left(t_{22,0.05}\right) s(C-U)}{\sqrt{n}} & \bar{x}_{(C-U)}-h w \leq \mu_{(C-U)} \leq \bar{x}_{(C-U)}+h w \\
h w & =\frac{(1.717) 0.67}{\sqrt{23}} & -0.22-0.24 \leq \mu_{(C-U)} \leq-0.22+0.24 \\
h w & =0.24 \text { unit per hour } & -0.46 \leq \mu_{(C-U)} \leq 0.02
\end{aligned}
$$

Given that the confidence interval about $\mu_{(\mathrm{C}-\mathrm{U})}$ includes zero, it is concluded that there is no significant difference in the mean throughput produced by calculation of maximum production capacity $\left(\mu_{\mathrm{C}}\right)$ and proposed u-shaped line in ProModel $\left(\mu_{\mathrm{U}}\right)$. Thus, the model of proposed u-shaped line in ProModel is right (validation and verification). There are 11,83 finished repair vehicles that are found in the finished stall. This is the output of proposed u-shaped line in the simulation.

\section{E. Analysis}

In order to prove that both proposed lines are better than the current line, the following graphs show the comparison between current and proposed line (straight line and u-shaped line).
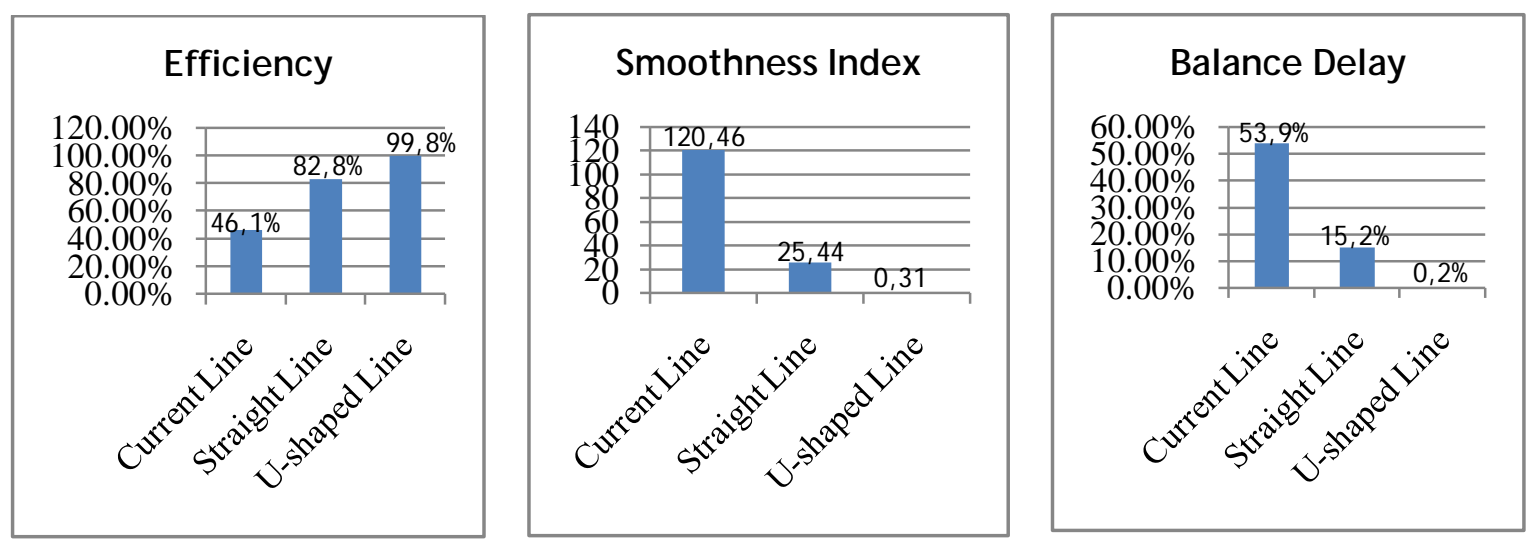

Figure 8. Comparison between Current, Straight, and U-shaped Line 
Figure 8 shows a significant improvement in line efficiency, smoothness index, and balance delay. Although both proposed lines are better than the current line, the proposed u-shaped line is the best line to implement in the body shop. The proposed ushaped line is significantly increasing the line efficiency and reducing the number of workstations. On contrast, the proposed u-shaped line is not significantly increasing the output of body shop because there is no significant difference between output of proposed straight line and output of proposed u-shaped line. This fact could happened because the main goal of proposed u-shaped line is minimizing the number of workstations. Therefore, the proposed u-shaped line is better than proposed straight line.

\section{CONCLUSION}

There are two ways to improve the line efficiency in the body shop; creating the accurate standard time by using time study and redesigning the assembly line through heuristic approaches (Rank Positional Weight for straight line balancing and Critical Task Method for u-shaped line balancing). The proposed u-shaped line is significantly increasing the line efficiency and reducing the number of workstations. On contrast, the proposed ushaped line is not significantly increasing the output of body shop because there is no significant difference between output of proposed straight line and output of proposed ushaped line. This fact could happened because the main goal of proposed u-shaped line is minimizing the number of workstations. Therefore, the proposed u-shaped line is better than proposed straight line.

\section{REFERENCES}

[1] Bagher, M., Zandieh, M. \& Farsijani, H. Balancing of Stochastic U-type Assembly Line: an Imperialist Competitive Algorithm. Int J Adv Manuf Technol. 2011.

[2] Barnes. Perancangan Keseimbangan Lintasan Produksi untuk Mengurangi Balance Delay dan Meningkatkan Efisiensi Kerja. Modul6 Perancangan Sistem Produksi Perakitan. 2011. Lab Sistem Produksi IE ITB.

[3] Fathi, M., Alvarez, M. J. \& Rodriguez, V. A New Heuristics Approach to Solving U-shape Assembly Line Balancing Problem Type-1. World Academy of Science, Engineering and Technology 59. 2011.

[4] Gasperz, Vincent. (1998). Statistical process control ManajemenBisnis Total. Jakarta: PT. GramediaPustakaUtama.

[5] Harrel, C., Ghosh, Biman K. \& Bowden, Royce O. (2012). Simulation using Promodel 3rd edition. New York: McGraw-hill education.

[6] Hayter, A., 2000. Probability and Statistics for Engineers and Scientists 3rd Edition. Thomson.

[7] Karger, D.W. \& Bahya, F.H. (1977). Engineering Work Measurement 3rd Edition. New York: The Industrial Press.

[8] Mahmud, A., Mahbubur R. \& Ahmad N. Study the Impact of Fatigue and Optimizing Productivity of an Assembly Line of Garment Industry. International Journal of Scientific and Engineering Research volume 2. Issue 11. 2011.

[9] Mulyati, Erna \& Rachmi, Ricca. Redesain Layout untuk Meningkatkan Efisiensi Ruangan. Politeknik Pos Indonesia. 2011.

[10] Niebel, B.W. \& Freivalds, A. (2003). Niebel's Methods, Standards, and Work Design 12th Edition. New York: McGraw-Hill.

[11] Sharma, R. (2009). Overview of Precedence Diagram Method (PDM).

[12] Sutalaksana, Iftikar Z., Anggawisastra, R. And Tjakraatmadja, J.H. (2006). Teknik Perancangan Sistem Kerja. Bandung: ITB.

[13] Verma, R. \& Boyer, Kenneth D. (2010). Operations \& Supply Chain Management. SouthWestern: Cengage Learning.

[14] Wignjosoebroto, S. (2000). Ergonomi, Studi Gerak dan Waktu. Surabaya: Guna Widya.

[15] Yeh, D. H. \& Kao, H. H. A New Bidirectional Heuristic for the Assembly Line Balancing Problem. Comput Indu Eng. Vol 57. No 4. pp. 1156-1160. 2009 


\section{APPENDICES}

\section{Appendix 1}

Standard Time after Time Study
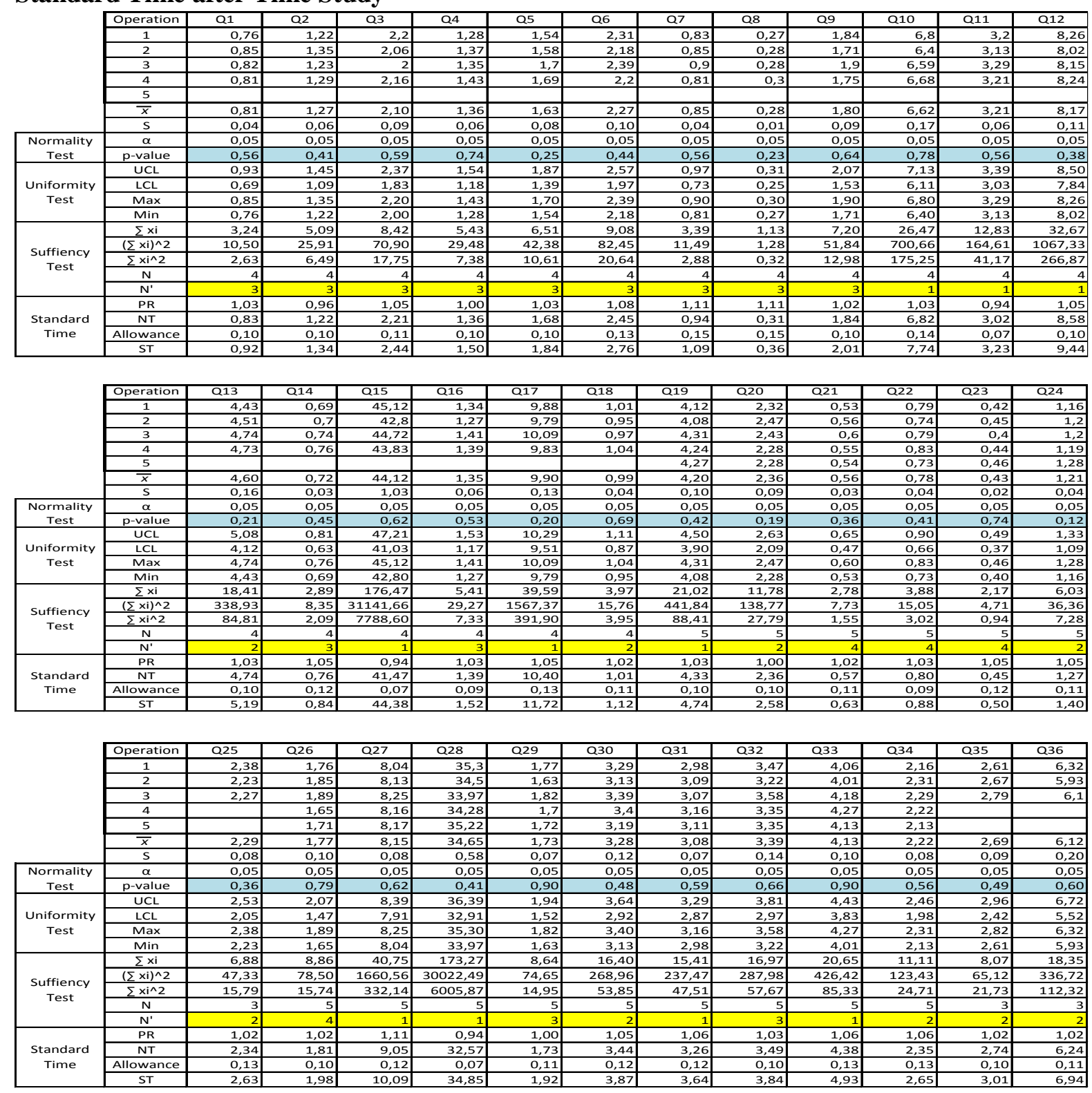

\begin{tabular}{|c|c|c|c|c|c|c|c|c|c|c|c|c|}
\hline & Operation & Q37 & Q38 & Q39 & Q40 & Q41 & Q42 & Q43 & Q44 & Q45 & Q46 & Q47 \\
\hline & 1 & 2,12 & 6,83 & 3,09 & 1,8 & 11,85 & \begin{tabular}{l|l|}
1,64 \\
\end{tabular} & 5,12 & 2,48 & 4,83 & 1,7 & 1,2 \\
\hline & 2 & 2,25 & 7,18 & 3,3 & 1,84 & 10,9 & 1,78 & 4,79 & 2,39 & 4,7 & 1,82 & 1,17 \\
\hline & 3 & 2,09 & 6,98 & 3,35 & 1,93 & 11,42 & 1,68 & 4,87 & 2,5 & 4,93 & 1,65 & 1,24 \\
\hline & 4 & & & & & & & & & & 1,68 & 1,28 \\
\hline & 5 & & & & & & & & & & & \\
\hline & $\bar{x}$ & 2,15 & 7,00 & 3,25 & 1,86 & 11,39 & 1,70 & 4,93 & 2,46 & 4,82 & 1,71 & 1,22 \\
\hline & $\mathrm{s}$ & 0,08 & 0,18 & 0,14 & 0,07 & 0,48 & \begin{tabular}{l|l|}
0,07 \\
\end{tabular} & 0,17 & 0,06 & 0,11 & 0,07 & 0,05 \\
\hline \multirow{2}{*}{$\begin{array}{c}\text { Normality } \\
\text { Test }\end{array}$} & $\alpha$ & 0,05 & 0,05 & 0,05 & 0,05 & 0,05 & 0,05 & 0,05 & 0,05 & 0,05 & 0,05 & 0,05 \\
\hline & $p$-value & 0,23 & 0,60 & 0,24 & 0,44 & 0,62 & 0,40 & 0,32 & 0,22 & 0,60 & 0,20 & 0,82 \\
\hline \multirow{4}{*}{$\begin{array}{c}\text { Uniformity } \\
\text { Test }\end{array}$} & $\mathrm{UCL}$ & 2,39 & 7,54 & 3,67 & 2,07 & 12,83 & 1,91 & 5,44 & 2,64 & 5,15 & 1,92 & 1,37 \\
\hline & $\mathrm{LCL}$ & 1,91 & 6,46 & 2,83 & 1,65 & 9,95 & 1,49 & 4,42 & 2,28 & 4,49 & 1,50 & 1,07 \\
\hline & Max & 2,25 & 7,18 & 3,35 & 1,93 & 11,85 & 1,78 & 5,12 & 2,50 & 4,93 & 1,82 & 1,28 \\
\hline & Min & 2,09 & 6,83 & 3,09 & 1,80 & 10,90 & 1,64 & 4,79 & 2,39 & 4,70 & 1,65 & 1,17 \\
\hline \multirow{5}{*}{$\begin{array}{c}\text { Suffiency } \\
\text { Test }\end{array}$} & $\sum x i$ & 6,46 & 20,99 & 9,74 & 5,57 & 34,17 & 5,10 & 14,78 & 7,37 & 14,46 & 6,85 & 4,89 \\
\hline & $\left(\sum x i\right)^{\wedge} 2$ & 41,73 & 440,58 & 94,87 & 31,02 & 1167,59 & 26,01 & 218,45 & 54,32 & 209,09 & 46,92 & 23,91 \\
\hline & $\sum x i^{\wedge} 2$ & 13,93 & 146,92 & 31,66 & 10,35 & 389,65 & 8,68 & 72,88 & 18,11 & 69,72 & 11,75 & 5,98 \\
\hline & $\mathrm{N}$ & 3 & 3 & 3 & 3 & 3 & 3 & 3 & 3 & 3 & 4 & 4 \\
\hline & $N^{\prime}$ & 2 & 1 & 2 & 2 & 2 & 2 & 2 & 1 & 1 & 3 & 2 \\
\hline \multirow{4}{*}{$\begin{array}{l}\text { Standard } \\
\text { Time }\end{array}$} & $\mathrm{PR}$ & 1,02 & 1,02 & \begin{tabular}{l|}
1,02 \\
\end{tabular} & 1,00 & 1,05 & \begin{tabular}{l|l}
1,02 \\
\end{tabular} & 1,02 & 1,02 & 1,02 & 0,95 & 1,05 \\
\hline & NT & 2,19 & 7,14 & 3,32 & 1,86 & 11,96 & \begin{tabular}{l|l}
1,73 \\
\end{tabular} & 5,03 & 2,51 & 4,92 & 1,62 & 1,28 \\
\hline & Allowance & 0,10 & 0,11 & 0,11 & 0,10 & 0,11 & 0,11 & 0,11 & 0,11 & 0,11 & 0,09 & 0,10 \\
\hline & ST & 2,41 & 7,95 & 3,68 & 2,04 & 13,31 & 1,93 & 5,60 & 2,79 & 5,47 & 1,77 & 1,41 \\
\hline
\end{tabular}




\section{Appendix 2}

Precedence Diagram

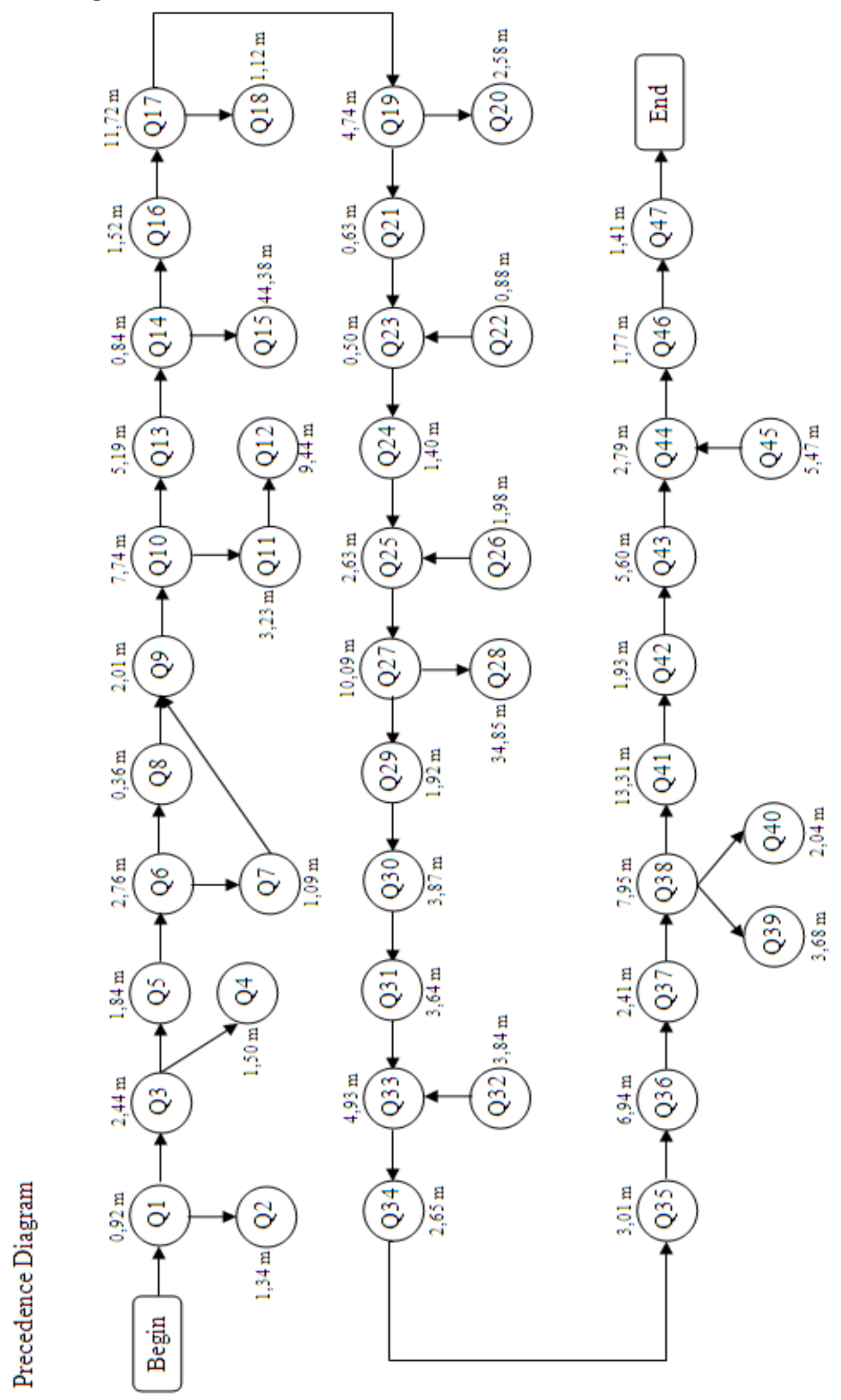




\section{Appendix 3}

\section{Rank Positional Weight}

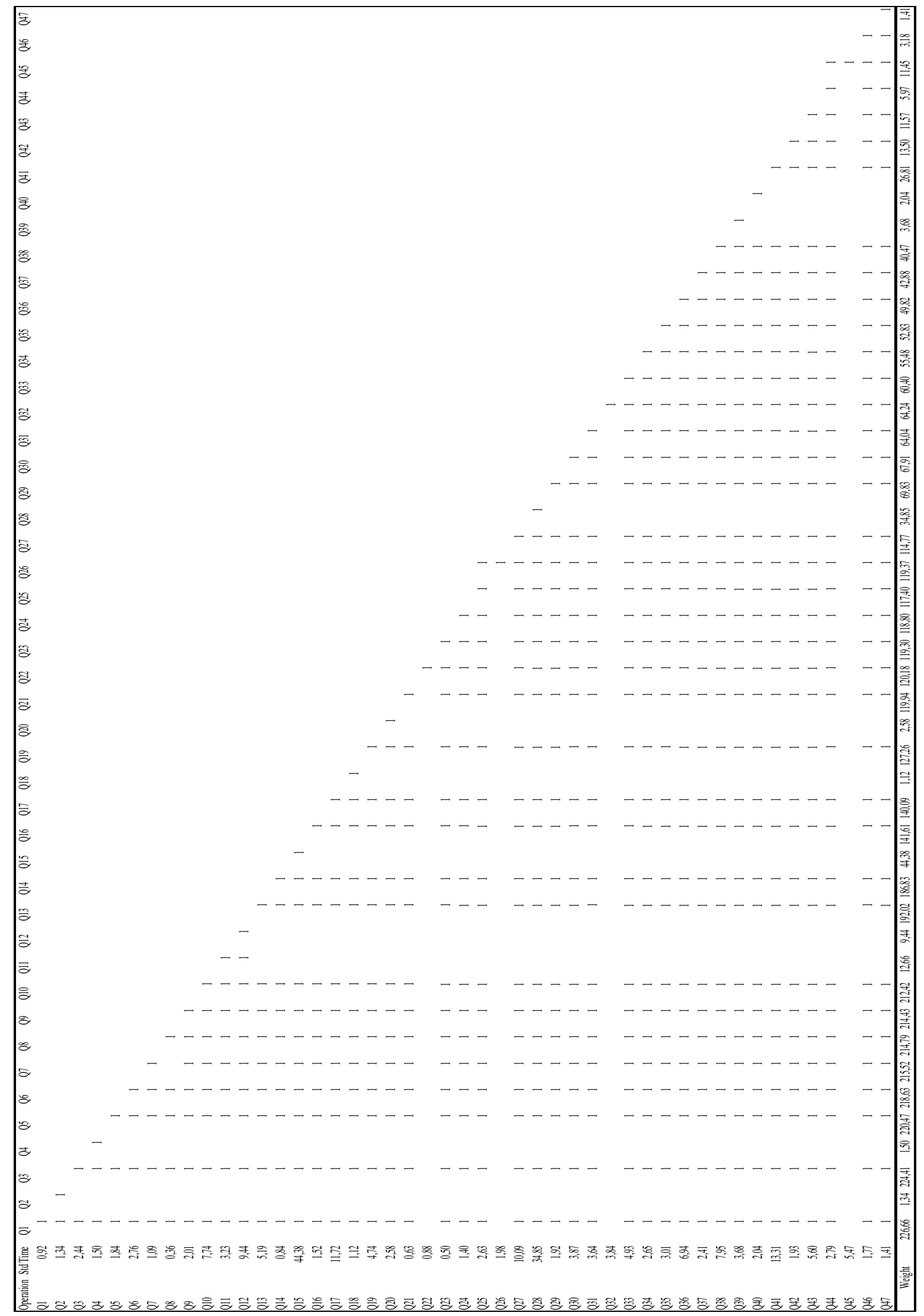


Following table shows how the combination is determined after having RPW

\begin{tabular}{|c|c|c|c|c|c|c|c|}
\hline $\begin{array}{l}\text { Workstati } \\
\text { on }\end{array}$ & $\begin{array}{l}\text { Work } \\
\text { Element }\end{array}$ & PW & $\begin{array}{l}\text { Immediate } \\
\text { Predecessor }\end{array}$ & Std Time & $\begin{array}{c}\text { Number of } \\
\text { Operator }\end{array}$ & $\begin{array}{c}\text { Cummulative per } \\
\text { workstation }\end{array}$ & $\begin{array}{l}\text { Unassigned per } \\
\text { Workstation }\end{array}$ \\
\hline 1 & Q1 & 226,66 & & \begin{tabular}{l|l|}
0,92 \\
\end{tabular} & 1 & 39,52 & 8,48 \\
\hline 1 & Q3 & 224,41 & Q1 & 2,44 & 1 & 39,52 & 8,48 \\
\hline 1 & Q5 & 220,47 & Q3 & 1,50 & 1 & 39,52 & 8,48 \\
\hline 1 & Q6 & 218,63 & Q5 & 2,76 & 1 & 39,52 & 8,48 \\
\hline 1 & Q7 & 215,52 & Q6 & \begin{tabular}{l|l|}
1,09 \\
\end{tabular} & 1 & 39,52 & 8,48 \\
\hline 1 & Q8 & 214,79 & Q6 & 0,36 & 1 & 39,52 & 8,48 \\
\hline 1 & $\overline{\mathrm{Q} 9}$ & \begin{tabular}{|c|}
214,43 \\
\end{tabular} & Q7, Q8 & 2,01 & 1 & 39,52 & 8,48 \\
\hline 1 & Q10 & 212,42 & Q9 & 7,74 & 1 & 39,52 & 8,48 \\
\hline 1 & Q13 & 192,02 & Q10 & 5,19 & 1 & 39,52 & 8,48 \\
\hline 2 & Q14 & 186,83 & Q13 & 0,84 & 1 & 46,74 & 1,26 \\
\hline 2 & Q16 & 141,61 & Q14 & \begin{tabular}{l|}
1,52 \\
\end{tabular} & 1 & 46,74 & 1,26 \\
\hline 3 & Q17 & 140,09 & Q16 & \begin{tabular}{l|l|}
11,72 \\
\end{tabular} & 1 & 26,2 & 21,8 \\
\hline 3 & Q19 & 127,26 & Q17 & 4,74 & 1 & 26,2 & 21,8 \\
\hline 3 & Q22 & 120,18 & & \begin{tabular}{l|l|l}
0,88 \\
\end{tabular} & 1 & 26,2 & 21,8 \\
\hline 3 & Q21 & 119,94 & Q19 & \begin{tabular}{l|l|}
0,63 \\
\end{tabular} & 1 & 26,2 & 21,8 \\
\hline 4 & Q26 & 119,37 & & 1,98 & 1 & 46,92 & 1,08 \\
\hline 3 & Q23 & 119,3 & Q21, Q22 & 0,50 & 1 & 26,2 & 21,8 \\
\hline 3 & Q24 & 118,8 & Q23 & 1,40 & 1 & 26,2 & 21,8 \\
\hline 3 & Q25 & 117,4 & Q24, Q26 & 2,63 & 1 & 26,2 & 21,8 \\
\hline 4 & Q27 & 114,77 & Q25 & \begin{tabular}{l|l|}
10,09 \\
\end{tabular} & 1 & 46,92 & 1,08 \\
\hline 5 & Q29 & 69,83 & Q27 & 1,92 & $\overline{1}$ & 44,84 & 3,16 \\
\hline 5 & Q30 & 67,91 & Q29 & 3,87 & 1 & 44,84 & 3,16 \\
\hline 5 & Q32 & 64,24 & & 3,84 & 1 & 44,84 & 3,16 \\
\hline 5 & Q31 & 64,04 & Q30 & 3,64 & 1 & 44,84 & 3,16 \\
\hline 5 & Q33 & 60,4 & Q31, Q32 & \begin{tabular}{l|l|}
4,93 \\
\end{tabular} & 1 & 44,84 & 3,16 \\
\hline 5 & Q34 & 55,48 & Q33 & 2,65 & 1 & 44,84 & 3,16 \\
\hline 5 & Q35 & 52,83 & Q34 & 3,01 & 1 & 44,84 & 3,16 \\
\hline 5 & Q36 & 49,82 & Q35 & 6,94 & 1 & 44,84 & 3,16 \\
\hline 2 & Q15 & 44,38 & Q14 & \begin{tabular}{l|l|}
44,38 \\
\end{tabular} & 1 & 46,74 & 1,26 \\
\hline 5 & Q37 & 42,88 & Q36 & 2,41 & 1 & 44,84 & 3,16 \\
\hline 5 & Q38 & \begin{tabular}{|l|}
40,47 \\
\end{tabular} & Q37 & \begin{tabular}{|l|}
7,95 \\
\end{tabular} & 1 & 44,84 & 3,16 \\
\hline 4 & Q28 & 34,85 & Q27 & 34,85 & 1 & 46,92 & 1,08 \\
\hline 6 & Q41 & 26,81 & Q38 & 13,31 & 1 & 34,32 & 13,68 \\
\hline 6 & Q42 & 13,5 & Q41 & 1,93 & 1 & 34,32 & 13,68 \\
\hline 1 & Q11 & 12,66 & Q10 & \begin{tabular}{l|}
3,23 \\
\end{tabular} & 1 & 39,52 & 8,48 \\
\hline 6 & Q43 & 11,57 & Q42 & 5,60 & 1 & 34,32 & 13,68 \\
\hline 6 & Q45 & 11,45 & & 5,47 & 1 & 34,32 & 13,68 \\
\hline 1 & Q12 & 9,44 & Q11 & 9,44 & 1 & 39,52 & 8,48 \\
\hline 6 & Q44 & 5,97 & Q43, Q45 & 2,79 & 1 & 34,32 & 13,68 \\
\hline 5 & Q39 & 3,68 & Q38 & 3,68 & 1 & 44,84 & 3,16 \\
\hline 6 & Q46 & 3,18 & Q44 & 1,77 & 1 & 34,32 & 13,68 \\
\hline 3 & Q20 & 2,58 & Q19 & 2,58 & 1 & 26,2 & 21,8 \\
\hline 6 & Q40 & 2,04 & Q38 & 2,04 & 1 & 34,32 & 13,68 \\
\hline 1 & $\mathrm{Q} 4$ & 1,5 & Q3 & \begin{tabular}{l|l|}
1,50 \\
\end{tabular} & 1 & 39,52 & 8,48 \\
\hline 6 & Q47 & 1,41 & Q46 & 1,41 & 1 & 34,32 & 13,68 \\
\hline 1 & Q2 & 1,34 & Q1 & 1,34 & 1 & 39,52 & 8,48 \\
\hline 3 & Q18 & 1,12 & Q17 & \begin{tabular}{l|l|}
1,12 \\
\end{tabular} & 1 & 26,2 & 21,8 \\
\hline
\end{tabular}




\section{Appendix 4 \\ Critical Task Method}

\begin{tabular}{|c|c|c|c|c|c|c|c|c|c|c|c|c|c|c|c|c|c|c|c|c|c|c|}
\hline 国政 & 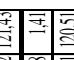 & 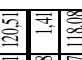 & 国 & & 量 & & & & & & & & & & & & & & & & & \\
\hline & 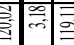 & ? & $\left.\right|^{m} \mid$ & & & & & & & & & & & & & & & & & & & \\
\hline & & & 䍘 & & 影里 & & & & & & & & & & & & & & & & & \\
\hline & & 周原 & & & 임을 & 周总 & & & 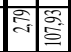 & & & & & & & & & & & & & \\
\hline & 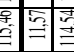 & & 事 & & 魚昜 & $=$ & & & & & 음궁 & & & & & & & & & & & \\
\hline & 商事 & 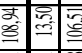 & 象: & 임믈 & 움혈 & 产 & & & 웡 & & 공영 & क्: & & & & & & & & & & \\
\hline & 僉高 & 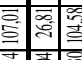 & 泡 & 商局 & 善善 & : & 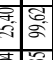 & & 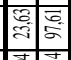 & $\sqrt{2}$ & 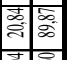 & & 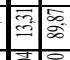 & & & & & & & & & \\
\hline 穼 & s: & 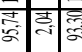 & 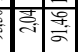 & & 웡류: & 疋商 & 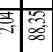 & & 穼范 & & 웡ㅇㅁㅇ & & & & 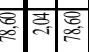 & & & & & & & \\
\hline & & 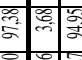 & \% & 局递 & 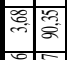 & 0 & 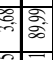 & & 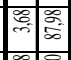 & 萬 & 离 & & & & है: & & & & & & & \\
\hline 原 & 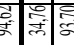 & 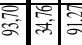 & 果 & 拿圆: & 周厓 & कि & 离 & & 욱 & & 象 & & & & & & & & & & & \\
\hline & 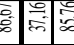 & 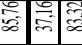 & 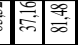 & 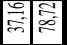 & 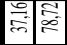 & \% & 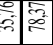 & & 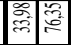 & in: & 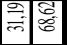 & & & & 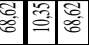 & & & & & & & \\
\hline 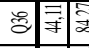 & 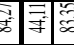 & 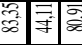 & 可 & 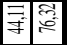 & 司㣢 & 司高 & 表 & $f$ & 翞总 & 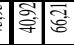 & 궁 & \% & $\infty$ & 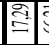 & 둥 & & & [5] & & & & \\
\hline 跣 & 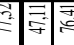 & 害㬏 & F & 周器 & 司管总 & 成治 & 家 & : & \%: & 骨学 & 㨌福 & 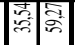 & & 웡 & 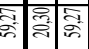 & & & {$[8]$} & & & [n & \\
\hline & 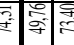 & 高淁 & i & $\left|\frac{9}{9}\right|$ & ब, & 产 & 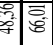 & $\left|\frac{8}{9}\right| \stackrel{8}{0}$ & 票部 & 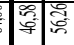 & 商施 & \% & & & 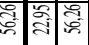 & & $\pi$ & \% & & & of & \\
\hline 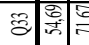 & is & $=0$ & 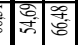 & 涪: 장 & : & 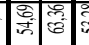 & : & & 语: & 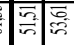 & 司事 & 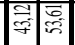 & 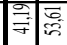 & & 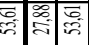 & ; & 善糙 & 高唹 & 80 & 尊 & 量 & 귴 \\
\hline & 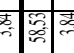 & 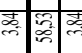 & 5 & 緭总 & 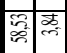 & & 㞼 & $t$ & की & 商㺃 & 商总 & 善冓 & & is & 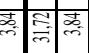 & & & if & & $\overrightarrow{0}$ & 总 & s. \\
\hline 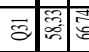 & 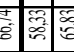 & 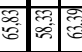 & 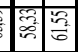 & 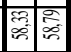 & 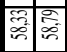 & 畜: & 毒 & 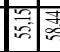 & 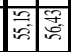 & 司递 & 商递 & 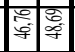 & 袶递 & 象 & 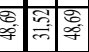 & & & 象圈 & & 新 & 矛 & 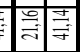 \\
\hline 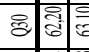 & (3) & 훟중 & क्षे & क्ष্亍ি: & 종류: & 活 & 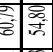 & 햄욤 & 㖆产 & 颜鸪 & 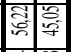 & 密: & & & 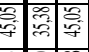 & & & 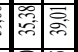 & & 居悉 & 里 & \\
\hline 영궁면 & 울 궁 & 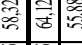 & 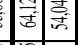 & 궁: & 몋율 & 司害 & 类 & 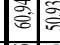 & 㐱尊 & 诸 & 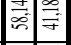 & 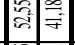 & 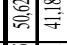 & & 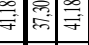 & & & 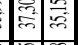 & & 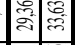 & 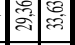 & \\
\hline : & 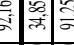 & 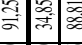 & 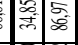 & 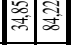 & 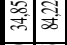 & 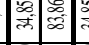 & 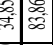 & 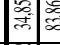 & 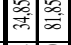 & 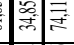 & 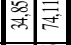 & 㟽豆 & 斠诖 & & 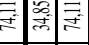 & & 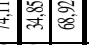 & $\mid \begin{array}{l}0 \\
0\end{array}$ & 语语 & 40 & & \\
\hline 화월 & 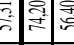 & 운문 & 골 & 䄈兽 & 程害 & 清豈 & 部产 & 言 & 월: & 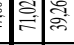 & 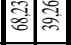 & 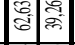 & 훙ㅎㅎ & & 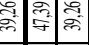 & & 4 & 筞语 & & $1 \overline{8}$ & 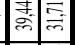 & \\
\hline \& & 司敨递 & 里商 & 票 & 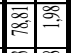 & 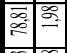 & & 镸 & 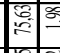 & $\begin{array}{c}\% \\
0\end{array}$ & $9 ;$ & 孞宩 & \begin{tabular}{|l|l|l|l|l|}
5 \\
\end{tabular} & 행웍 & क्ष: & 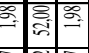 & & & 象赵- & & 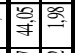 & 淁客 & 诧 \\
\hline 龱行 & 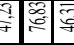 & 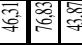 & 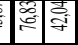 & 滵涪 & 离: & 䨓: & 语扂 & 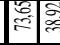 & 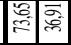 & 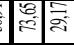 & 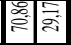 & 商离 & 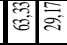 & & 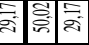 & & & 语语 & 1 & 宇 & 穼运 & 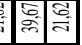 \\
\hline 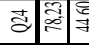 & 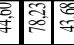 & : & : & : & ;: & 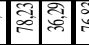 & : & 贯: & 溶害 & 善裹 & 福畹 & 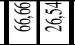 & 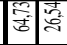 & 곡: & 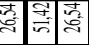 & & 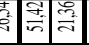 & 涪高 & 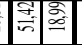 & 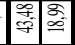 & 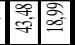 & $=$ \\
\hline 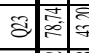 & 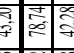 & ; & : & 串圆 & 事: & 展: & 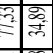 & 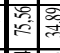 & 通必 & 递吉 & 於话 & 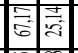 & 溶素 & & $\begin{array}{l}\text { : } \\
0\end{array}$ & & 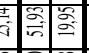 & 讋司 & & 㐿旁 & 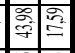 & 粉 \\
\hline 졍유:열 & 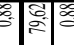 & 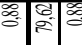 & क्षें & 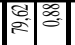 & 휠:要 & 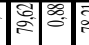 & 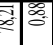 & 柔事 & 表: & 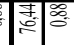 & 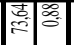 & 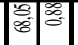 & 당: & : & 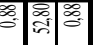 & & जी०1 & 商象 & $\mid$ & 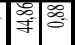 & 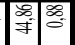 & $\frac{9}{9}$ \\
\hline 西养: & 语: & 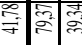 & 商 & 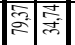 & 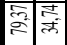 & 商商 & 橗高 & \% & 产器 & 울 & 是过 & 商部 & 鹿等 & & 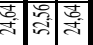 & & 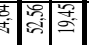 & 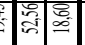 & & 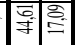 & 滰冚 & 雨结 \\
\hline 字通沀 & 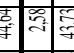 & অ: & : & 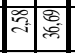 & 䨗: & 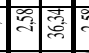 & 䆑惫 & 禺 & 吢哭 & 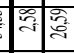 & 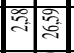 & 事递 & 来: & 象 & 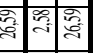 & & 受事 & 象递 & 事部 & 事总 & 事䄅 & 1 \\
\hline 放语事 & 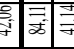 & 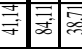 & 可 & 㬏诂 & 司语 & 诂商 & 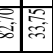 & ॠ & क्: & 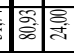 & : & 事部 & & 하ำ & 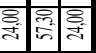 & 觔 & 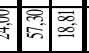 & 商迢 & & 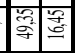 & 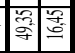 & 俤 \\
\hline$a=$ & 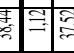 & 고예= & $\frac{1}{3}$ & 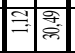 & 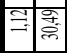 & $\exists=$ & $\exists$ & $\exists=\frac{\pi}{\pi}$ & 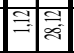 & 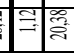 & $\exists=$ & ㅈ=ㅇㅎㅎ & 事兹 & $\approx=$ & 商 & 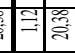 & $\because \approx$ & 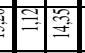 & $\approx \approx=\pi$ & $\approx \approx$ & $\approx \approx$ & 1 \\
\hline ㅎㅇㅇㅇㅠ & 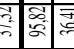 & 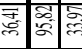 & 产 & 象商 & : & 商事 & 部茫 & क्षें: & 棓氞 & 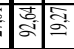 & 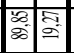 & 部要 & 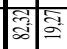 & 氞影 & 氞国害 & 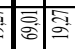 & 涪得 & 항ㅎㅁ & & 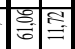 & 果: & : \\
\hline 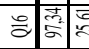 & 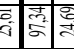 & & 商 & 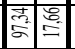 & 䓂果 & 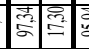 & 공율 & 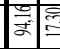 & : & 9 & 产哭 & 害量 & 范哭 & $T^{2}$ & 量器 & 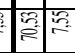 & 果: & 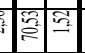 & & & 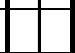 & 1 \\
\hline 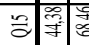 & 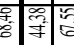 & 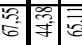 & 等 & 氶焉 & 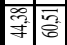 & 学递 & 焉: & 等递 & 学兽 & 学彜 & 萳青 & 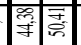 & 挐君 & 粱 & 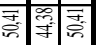 & 常学素 & 商拳 & 前学学 & 粰学 & 㭩学 & 爭学 & 粱 \\
\hline 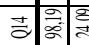 & 接: & 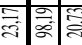 & क्षे: & : : & : & : & 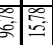 & : & 향윰 & 항; & ন্ন: & 㴦: & 漯: & 월 & 要商: & 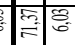 & bo & & & & & \\
\hline$\approx$ & 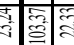 & 商涌递 & & 궁융 & 商产 & 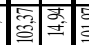 & 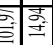 & 音接 & : & क्: & 衰高 & 商高 & : & & 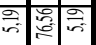 & 商产 & & & & & & \\
\hline & 它承高 & & Fit & Fit & की & A & & 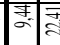 & 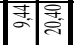 & 教递 & : & & Fi: & & 承串递 & & 舟: & 事 & & & & \\
\hline : $\mid$ & 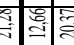 & 商承: & : & 害养 & 新荡 & 肃造 & & 笔 & 逢圈 & : & 通 & 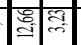 & : :्व: & & ন্লন & 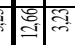 & 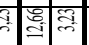 & में & & 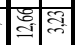 & 苛 & 5 \\
\hline о & 璟同 & & & & 国部 & 同 & & & & & & & & & & & & & & & & \\
\hline & 尝部 & 骨) & & & : & $=$ & & & & & & & & & & & & & & & & \\
\hline & 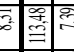 & क्रें & : & 荨递 & 象递 & & & & & & & & & & & & & & & & & \\
\hline & ; & क् & & & & & & & & & & & & & & & & & & & & \\
\hline & 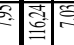 & ; & & & & & & & & & & & & & & & & & & & & \\
\hline & 5 & 7 & & & & & & & & & & & & & & & & & & & & \\
\hline & & & & & & & & & & & $\rightarrow 1$ & & & & & & 4 & 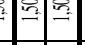 & & & & \\
\hline & : & & & & & & & & & & & & & & & & & & & & & \\
\hline & 7 & 1 & & 际 & $\because=$ & & & & 象事 & 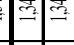 & 等 & 要 & & & je & & 国苟 & 事过事 & & & & 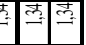 \\
\hline & & & & & & & & & & & & & & & & & & & & & & \\
\hline 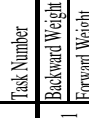 & 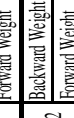 & 䇾 & & & & & & & & & & & & & & & & & & & & $\underline{5}$ \\
\hline
\end{tabular}




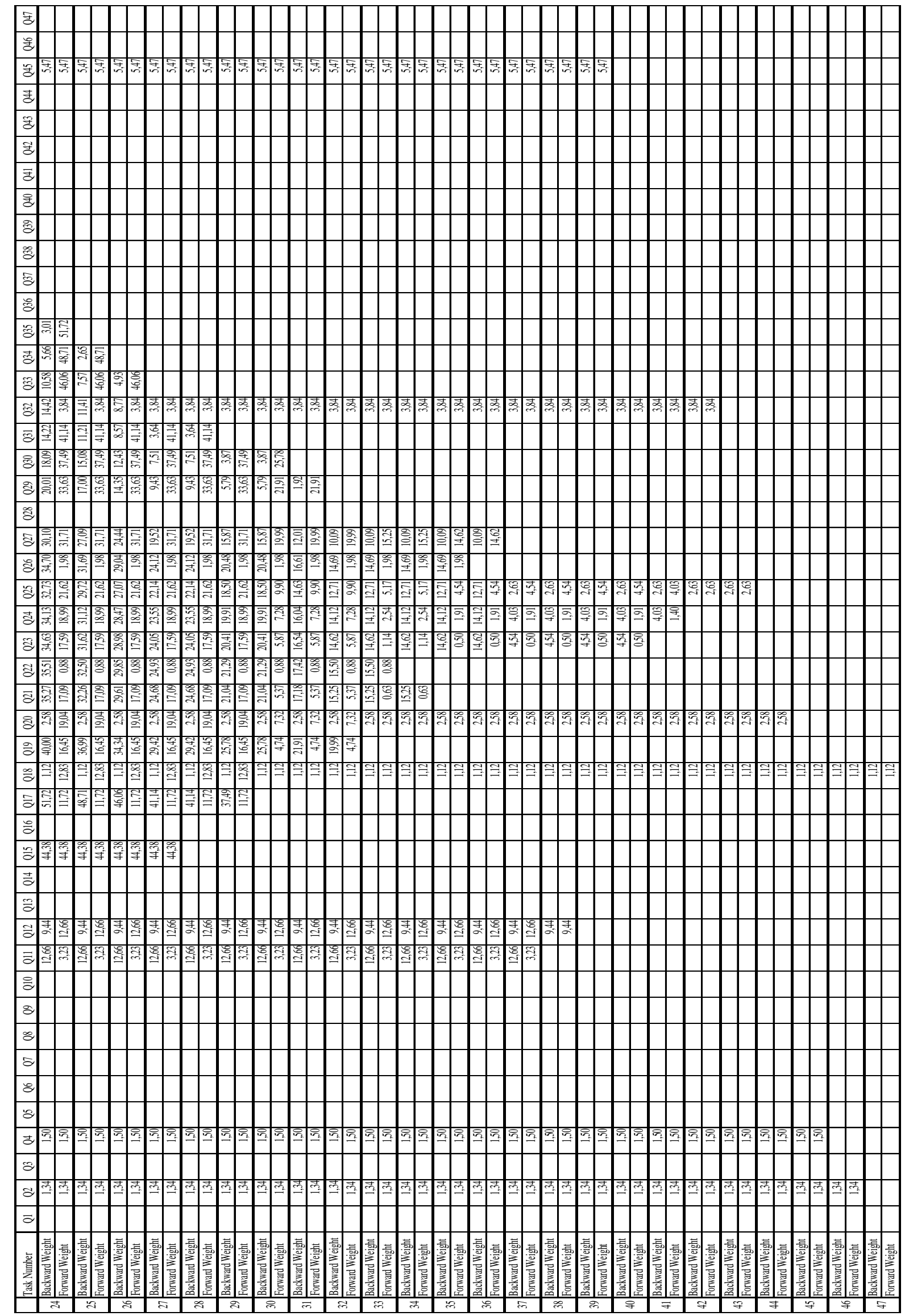




\begin{tabular}{|c|c|c|c|c|}
\hline Iteration & Candidate List & Assigned Task & Task Time & Station No. \\
\hline 1 & Q1,Q47 & Q1 & 0,92 & 1 \\
\hline 2 & $\mathrm{Q} 3, \mathrm{Q} 47$ & Q3 & 2,44 & 1 \\
\hline 3 & $\mathrm{Q} 5, \mathrm{Q} 47$ & Q5 & 1,84 & 1 \\
\hline 4 & $Q 6, Q 47$ & Q6 & 2,76 & 1 \\
\hline 5 & Q7 & Q7 & 1,09 & 1 \\
\hline 6 & $Q 8, Q 47$ & Q8 & 0,36 & 1 \\
\hline 7 & $Q 9, Q 47$ & Q47 & 1,41 & 2 \\
\hline 8 & Q9,Q46 & Q46 & 1,77 & 2 \\
\hline 9 & Q9,Q44 & Q9 & 2,01 & 2 \\
\hline 10 & Q10,Q44 & Q10 & 7,74 & 2 \\
\hline 11 & Q13,Q44 & Q44 & 2,79 & 2 \\
\hline 12 & Q13,Q43 & Q43 & 5,60 & 2 \\
\hline 13 & $\mathrm{Q} 13, \mathrm{Q} 42$ & Q42 & 1,93 & 2 \\
\hline 14 & Q13,Q41 & Q41 & 13,31 & 2 \\
\hline 15 & Q39 & Q39 & 3,68 & 2 \\
\hline 16 & Q40 & Q40 & 2,04 & 2 \\
\hline 17 & Q13,Q38 & Q13 & 5,19 & 3 \\
\hline 18 & Q14,Q38 & Q14 & 0,84 & 4 \\
\hline 19 & Q16,Q38 & Q16 & 1,52 & 4 \\
\hline 20 & Q17,Q38 & Q38 & 7,95 & 1 \\
\hline 21 & Q28 & Q28 & 34,85 & 5 \\
\hline 22 & Q17,Q37 & Q37 & 2,41 & 1 \\
\hline 23 & Q17,Q36 & Q36 & 6,94 & 1 \\
\hline 24 & Q17,Q35 & Q35 & 3,01 & 1 \\
\hline 25 & Q17,Q34 & Q34 & 2,65 & 1 \\
\hline 26 & Q17,Q33 & Q33 & 4,93 & 1 \\
\hline 27 & Q15 & Q15 & 44,38 & 4 \\
\hline 28 & Q17,Q31 & Q31 & 3,64 & 1 \\
\hline 29 & Q17,Q30 & Q17 & 11,72 & 3 \\
\hline 30 & Q19,Q30 & Q30 & 3,87 & 3 \\
\hline 31 & Q19,Q29 & Q29 & 1,92 & 3 \\
\hline 32 & Q19,Q27 & Q19 & 4,74 & 3 \\
\hline 33 & Q22 & Q22 & 0,88 & 5 \\
\hline 34 & $\mathrm{Q} 21, \mathrm{Q} 27$ & Q21 & 0,63 & 3 \\
\hline 35 & Q26 & Q26 & 1,98 & 5 \\
\hline 36 & Q23,Q27 & Q27 & 10,09 & 5 \\
\hline 37 & Q11,Q12 & Q11 & 3,23 & 3 \\
\hline 38 & Q12 & Q12 & 9,44 & 3 \\
\hline 39 & Q45 & Q45 & 5,47 & 2 \\
\hline 40 & Q23,Q25 & Q23 & 0,50 & 3 \\
\hline 41 & Q24,Q25 & Q24 & 1,40 & 3 \\
\hline 42 & Q32 & Q32 & 3,84 & 1 \\
\hline 43 & Q25 & Q25 & 2,63 & 3 \\
\hline 44 & Q20 & Q20 & 2,58 & 3 \\
\hline 45 & Q4 & Q4 & 1,50 & 1 \\
\hline 46 & Q2 & Q2 & 1,34 & $I_{1}$ \\
\hline 47 & Q18 & Q18 & 1,12 & 4 \\
\hline
\end{tabular}

